\title{
Analisis Kadar Timbal (Pb) Air Minum Isi Ulang pada Depot Air Minum (DAM) di Kecamatan Padang Timur Kota Padang Tahun 2017
}

Fitri Wahyu Febriwani ${ }^{1}$, Aisyah Elliyanti ${ }^{2}$, Mohamad Reza ${ }^{3}$

\begin{abstract}
Abstrak
Air minum isi ulang yang diperoleh dari Depot Air Minum (DAM) menjadi populer karena harganya lebih murah dari Air Minum Dalam Kemasan (AMDK) yang bermerek. Apabila air minum isi ulang terkontaminasi dengan timbal $(\mathrm{Pb})$ akan menyebabkan masalah terhadap kesehatan. Tujuan: Menganalisis kadar $\mathrm{Pb}$ air minum isi ulang pada DAM di Kecamatan Padang Timur tahun 2017. Metode: Penelitian ini adalah studi analitik. Sampel diambil dari 45 DAM di Kecamatan Padang Timur. Penelitian dilakukan pada bulan November sampai Desember 2017. Data dianalisis dengan uji Mann-Whitney. Hasil: 100\% kadar Pb kecil dari atau sama dengan Nilai Ambang Batas (NAB) sesuai peraturan Permenkes No. 492 tahun 2010. Ada 95,6\% sumber air minum isi ulang berasal dari Gunung Talang Kabupaten Solok, 100\% DAM menggunakan pipa PVC tipe AW, dan 51,1\% DAM menggunakan pipa PVC dengan lama pemakaian $<5$ tahun. Hasil uji statistik didapatkan bahwa tidak terdapat hubungan bermakna antara sumber air minum dan lamanya pemakaian pipa terhadap kadar $\mathrm{Pb}$ air minum isi ulang pada DAM di Kecamatan Padang Timur tahun 2017. Terdapat 100\% pipa PVC pada DAM menggunakan tipe AW sehingga tidak dapat dilakukan uji statistik. Simpulan: Kadar Pb air minum isi ulang pada DAM di Kecamatan Padang Timur Kota Padang tahun 2017 masih aman untuk dikonsumsi dan pipa PVC tipe AW aman untuk digunakan dalam rentang waktu tertentu.
\end{abstract}

Kata kunci: timbal, pipa PVC, lama pemakaian, air minum isi ulang

\section{Abstract}

Drinking water refills obtained from Drinking Water Stations (DWS) are popular because they are cheaper than the branded drinking waters. If the drinking water refills are contaminated by lead $(P b)$ it can cause health problems. Objectives: To analyzed the level of $\mathrm{Pb}$ in drinking water refills taken from drinking water stations (DWS) in East Padang Subdistrict 2017. Methods: The research is an analytical study. The samples were taken from 45 DWS in East Padang Subdistrict. This study was conducted from November to December 2017. The data were analyzed by Mann-Whitney test. Results: There were $100 \%$ level of $\mathrm{Pb}$ is less than or same with the treshold value approved by Permenkes Regulation No. 492 in 2010, the source of drinking water refills taken from Mount Talang District of Solok are $95,6 \%, 100 \%$ DWS are using AW type of PVC pipes, and 51.1\% DWS are using PVC pipes with duration of use less than five years. The statistical test showed that there are no significant correlation between drinking water source and the duration of pipe usage with the level of Pb of drinking water refills at DWS in East Padang Subdistrict 2017. 100\% DWS use AW type of PVC pipe so that statistic test can not be analyzed. Conclusion: The lead level in the drinking water refills is still safe to be consumed and the AW type of PVC pipe is safe to be used until a certain period. Keywords: lead, PVC pipe, duration of use, drinking water refill

Affiliasi penulis: 1. Prodi Pendidikan Dokter Fakultas Kedokteran Universitas Andalas Padang) (FK Unand), 2. Bagian Fisika FK Unand, 3. Bagian Biologi FK Unand
Korespondensi: Fitri Wahyu Febriwani, Email: fitri_febriwani@yahoo.com, Telp: 081381606974 


\section{PENDAHULUAN}

Air adalah zat yang penting bagi tubuh manusia setelah udara. Air dipergunakan untuk banyak hal seperti untuk mencuci, memasak, minum dan lain-lain. Namun, air yang digunakan untuk minum harus mempunyai kualitas yang lebih tinggi daripada air yang digunakan untuk mencuci, memasak dan kebutuhan lainnya. Hal ini disebabkan karena air tersebut akan masuk ke dalam tubuh manusia. ${ }^{1,2}$

Ketersediaan air bersih terbatas karena terjadi pengurangan sampai $40 \%$ sumber air bersih di kotakota besar yang disebabkan karena kurang baiknya fasilitas air yang ada dan juga karena pencemaran. Pencemaran air oleh logam berbahaya maupun mikroba dapat memberikan dampak yang berbahaya untuk kesehatan. Adanya beragam kasus pencemaran pernah dilaporkan di negara maju maupun negara berkembang. Logam yang terkandung dalam air seperti di sungai biasanya berasal dari buangan air limbah, erosi, dan dari udara secara langsung. ${ }^{1,2}$

Seiring dengan perekonomian dan kesibukan yang dijalani oleh masyarakat, maka pengadaan air minum di rumah lebih mengutamakan kepraktisan dan harga yang relatif lebih murah, tidak sedikit masyarakat di rumah yang menggunakan air minum isi ulang yang dijual di depot-depot air minum (DAM) sebagai air minum yang mereka konsumsi. ${ }^{3}$

Menurut survei yang telah dilakukan oleh penulis, harga air minum isi ulang yang terdapat di depot-depot tersebut berkisar sepertiga dari harga air minum bermerek/Air Minum Dalam Kemasan (AMDK) dengan volume yang sama. Data Riset Kesehatan Dasar (Riskesdas) 2010 tentang proporsi sumber air minum rumah tangga di Indonesia, air minum isi ulang merupakan sumber air minum yang paling banyak digunakan oleh masyarakat Indonesia (14\%) setelah sumur gali terlindung. ${ }^{4}$

Data Riskesdas Sumatera Barat tahun 2013, DAM merupakan jenis sumber air minum terbanyak yang digunakan masyarakat Kota Padang $(55,4 \%) .{ }^{5}$ Berdasarkan data resmi dari Dinas Kesehatan Kota Padang, jumlah DAM di Kecamatan Padang Timur yang terdaftar cukup banyak yaitu berjumlah 72 depot dari total depot di Kota Padang yang berjumlah 618 depot $(12 \%)$, tidak semua air minum isi ulang pada DAM tersebut memiliki kualitas air dengan kelayakan minum yang telah terjamin dan memiliki surat izin yang masih berlaku dari Dinas Kesehatan Kota Padang. ${ }^{6}$

Pemeriksaan mutu produk air dilakukan agar air yang dihasilkan sesuai dengan persyaratan kualitas air minum menurut Peraturan Menteri Kesehatan Republik Indonesia (Permenkes RI) Nomor 492/MENKES/PER/IV/2010, yaitu meliputi parameter fisik, kimiawi, bakteriologis dan radioaktif. ${ }^{7}$ Sesuai parameter kimiawi, air minum tidak boleh mengandung zat-zat anorganik dan organik melebihi standar yang ditetapkan serta memiliki pH antara 6,5-8,5. Zat anorganik terdiri dari arsen (As), kadmium (Cd), nitrit $\left(\mathrm{NO}_{2}{ }^{-}\right)$, nitrat $\left(\mathrm{NO}_{3}{ }^{-}\right)$, mangan $(\mathrm{Mn})$, tembaga $(\mathrm{Cu})$, timbal $(\mathrm{Pb})$, dan berbagai macam logam lainnya. Sedangkan zat organik dapat berupa deterjen, chlorinated alkanes, chlorinated ethenes, aromatic hydrocarbons, dan berbagai macam zat organik lainnya. $^{7}$

Timbal $(\mathrm{Pb})$ merupakan salah satu jenis logam berat yang sering juga disebut dengan istilah timah hitam (plumbum). $\mathrm{Pb}$ biasa digunakan untuk melapisi logam agar tidak timbul perkaratan. ${ }^{8}$ Salah satu aplikasinya adalah penggunaan $\mathrm{Pb}$ pada pipa pengaliran air minum dan solder penyambungan pipa tersebut. ${ }^{9}$ Hal ini menyebabkan kemungkinan kontaminasi $\mathrm{Pb}$ pada air Perusahaan Daerah Air Minum (PDAM) dapat terjadi. ${ }^{10}$

Pernyataan tersebut terbukti dari penelitian yang dilakukan oleh Putri (2017) tentang kadar $\mathrm{Pb}$ yang terkandung pada air Perusahaan Daerah Air Minum (PDAM) di rumah penduduk di Desa Sijantang Koto Kecamatan Talawi Kota Sawahlunto Sumatera Barat. Hasil penelitian tersebut didapatkan 100\% air PDAM yang dijadikan air minum telah melebihi Nilai Ambang Batas (NAB) Menurut Permenkes RI Nomor 492/MENKES/PER/IV/2010 (NAB $=0,01 \mathrm{mg} / \mathrm{L}){ }^{10}$

Kontaminasi $\mathrm{Pb}$ terhadap sumber air minum lainnya juga ditemukan pada penelititan lain mengenai kadar $\mathrm{Pb}$ pada air sumur bor di Kecamatan Belawan Kota Medan. Hasil penelitian tersebut didapatkan 20\% sampel melebihi NAB. ${ }^{11}$ Penelitian yang dilakukan oleh Firmansyah et al. mendapatkan $60 \%$ sampel yang diambil dari mata air Pegunungan Guci, Kabupaten Tegal, Jawa Tengah mengandung kadar $\mathrm{Pb}$ diatas NAB. Sampel diambil dari tempat yang sering dilewati kendaraan bermotor yang 
berkemungkinan besar menjadi penyebab kadar $\mathrm{Pb}$ yang terkandung menjadi diatas NAB. ${ }^{12} \mathrm{~Pb}$ digunakan sebagai zat aditif untuk bahan bakar kendaraan bermotor yang keluar dari asap knalpot kendaraan. ${ }^{13}$

Timbal sebagai zat aditif untuk bahan bakar kendaraan bermotor, juga digunakan sebagai pelapis pada pipa polyvinyl chloride (PVC). ${ }^{13}$ Pipa PVC dapat digunakan sebagai pipa air minum termasuk pada pipa yang terdapat pada mesin pengolahan DAM. Pipa PVC digunakan secara luas oleh masyarakat karena memiliki harga yang murah, dapat diaplikasikan secara luas, dan tahan lama (40-50 tahun pemakaian). Senyawa $\mathrm{Pb}$ dalam PVC digunakan sebagai heat stabilizers. ${ }^{14}$ Pipa PVC terdiri dari berbagai macam tipe, yaitu tipe AW, tipe $D$ dan tipe C. ${ }^{15}$ Tipe AW merupakan pipa yang paling tebal. Pipa ini dirancang mampu menahan tekanan sampai $10 \mathrm{~kg} / \mathrm{cm}^{2}$. Sehingga biasanya digunakan untuk instalasi pipa air yang memiliki tekanan (menggunakan pompa) seperti yang digunakan di DAM. Tipe $D$ hanya mampu menahan tekanan sampai $5 \mathrm{~kg} / \mathrm{cm}^{2}$. Sedangkan pipa tipe $\mathrm{C}$ merupakan pipa yang paling tipis. ${ }^{15}$ Tekanan air pada pipa PVC yang tinggi dapat menyebabkan tingginya ekstraksi (pelepasan) dari $\mathrm{Pb}$ itu sendiri. Sehingga pipa tipe AW memiliki kemungkinan mengekstraksikan $\mathrm{Pb}$ lebih besar daripada pipa PVC tipe $\mathrm{D}$ dan $\mathrm{C}^{16}$

Ekstraksi $\mathrm{Pb}$ dari pipa dapat juga terjadi karena pengaliran air dalam pipa tersebut. ${ }^{14}$ Semakin lama pemakaian dari pipa PVC tersebut maka ekstraksi dari $\mathrm{Pb}$ tersebut juga semakin menurun karena kandungan $\mathrm{Pb}$ yang terdapat dalam pipa tersebut sudah berkurang seiring dengan pemakaian. ${ }^{14}$

Kadar $\mathrm{Pb}$ yang melebihi ambang batas konsumsi pada tubuh akan mengakibatkan keracunan dalam tubuh. Tidak seperti logam lain, dampak $\mathrm{Pb}$ menyebabkan terganggunya kesehatan pada hampir semua sistem tubuh manusia diantaranya dapat menyebabkan anemia, ensefalopati, penurunan pendengaran tipe sensorineural, penyakit renal progresif, takikardia, aritmia, infertilitas, gangguan pertumbuhan janin dan lain sebagainya. ${ }^{17}$ Pada orang dewasa hal ini ditandai dengan gejala seperti pucat, bahkan dapat menyebabkan kelumpuhan. ${ }^{3}$ Pada anak, akumulasi $\mathrm{Pb}$ dapat menyebabkan gangguan pada fase awal pertumbuhan fisik dan mental yang kemudian berakibat pada penurunan fungsi kecerdasan dan kemampuan akademik yang apabila berlangsung dalam jangka waktu yang lama, $\mathrm{Pb}$ akan terakumulasi pada gigi, gusi dan tulang. Jika peningkatan kadar $\mathrm{Pb}$ terus berlangsung, akan terjadi anemia dan kerusakan fungsi otak serta kegagalan fungsi ginjal. $^{3}$

\section{METODE}

Jenis penelitian ini adalah studi analitik observasional dengan desain cross sectional untuk mengetahui hubungan masing-masing variabel independen yaitu, sumber air minum isi ulang pada DAM, tipe pipa PVC dan lama pemakaian pipa PVC dengan kadar $\mathrm{Pb}$ air minum isi ulang pada DAM di Kecamatan Padang Timur. Penelitian dilakukan bulan November sampai Desember 2017. Populasi adalah seluruh DAM yang berada di Kecamatan Padang Timur di Kota Padang. Teknik pengambilan sampel disproportionate stratified random sampling. Analisis data pada penelitian ini adalah analisis univariat dan analisis bivariat. Analisis univariat untuk mengetahui distribusi frekuensi kadar $\mathrm{Pb}$, sumber air minum isi ulang, tipe pipa PVC dan lama pemakaian pipa PVC pada DAM. Analisis bivariat untuk mengetahui hubungan sumber air minum isi ulang pada DAM dengan kadar $\mathrm{Pb}$ air minum isi ulang, hubungan tipe pipa PVC yang digunakan pada DAM dengan kadar $\mathrm{Pb}$ air minum isi ulang dan lama pemakaian pipa PVC yang digunakan pada DAM dengan kadar $\mathrm{Pb}$ air minum isi ulang.

\section{HASIL}

Tabel 1. Distribusi frekuensi kadar $\mathrm{Pb}$ air minum isi ulang

\begin{tabular}{lcc}
\hline Kadar Pb & Frekuensi & $\%$ \\
\hline$\leq \mathrm{NAB}$ & 45 & 100,0 \\
$>\mathrm{NAB}$ & 0 & 0,0 \\
Total & $\mathbf{4 5}$ & $\mathbf{1 0 0} \%$ \\
\hline
\end{tabular}

Tabel 1 menunjukan bahwa seluruh sampel air minum isi ulang pada DAM di Kecamatan Padang Timur memiliki kadar $\mathrm{Pb}$ kecil dari atau sama dengan Nilai Ambang Batas (NAB) yaitu $\leq 0,01 \mathrm{mg} / \mathrm{L}$. 
Tabel 2. Distribusi frekuensi sumber air minum isi ulang

\begin{tabular}{lcc}
\hline Sumber & Frekuensi & $\%$ \\
\hline Gunung Talang, Solok & 43 & 95,6 \\
Sumur Bor & 2 & 4,4 \\
PDAM & 0 & 0,0 \\
Total & $\mathbf{4 5}$ & $\mathbf{1 0 0} \%$ \\
\hline
\end{tabular}

Tabel 2 menunjukan bahwa 43 sampel air minum isi ulang bersumber dari Gunung Talang, Kabupaten Solok (95,6\%) dan sisanya berasal dari sumur bor (4,4\%). Tidak terdapat DAM yang menggunakan sumber air minum yang berasal dari $\operatorname{PDAM}(0,0 \%)$.

Tabel 3. Distribusi Frekuensi Tipe Pipa PVC

\begin{tabular}{|c|c|c|}
\hline $\begin{array}{l}\text { Tipe pipa } \\
\text { PVC }\end{array}$ & Frekuensi & $\%$ \\
\hline AW & 45 & 100,0 \\
\hline$D$ & 0 & 0,0 \\
\hline C & 0 & 0,0 \\
\hline Total & 45 & $100 \%$ \\
\hline
\end{tabular}

Tabel 3 menunjukan bahwa semua DAM yang diambil sampelnya menggunakan pipa PVC tipe AW (100\%).

Tabel 4. Distribusi Frekuensi Lama Pemakaian Pipa PVC

\begin{tabular}{ccr}
\hline $\begin{array}{c}\text { Lama pemakaian } \\
\text { pipa }\end{array}$ & Frekuensi & $\%$ \\
\hline$<5$ tahun & 23 & 51,1 \\
$\geq 5$ tahun & 22 & 48,9 \\
Total & 45 & $100 \%$ \\
\hline
\end{tabular}

Tabel 4 menunjukan bahwa 23 DAM yang diambil sampelnya menggunakan pipa PVC pada mesin pengolahan DAM-nya dengan lama pemakaian kurang dari 5 tahun $(51,1 \%)$ dan sisanya lebih dari sama 5 tahun $(48,9 \%)$.
Tabel 5. Hubungan sumber air minum isi ulang dengan kadar $\mathrm{Pb}$

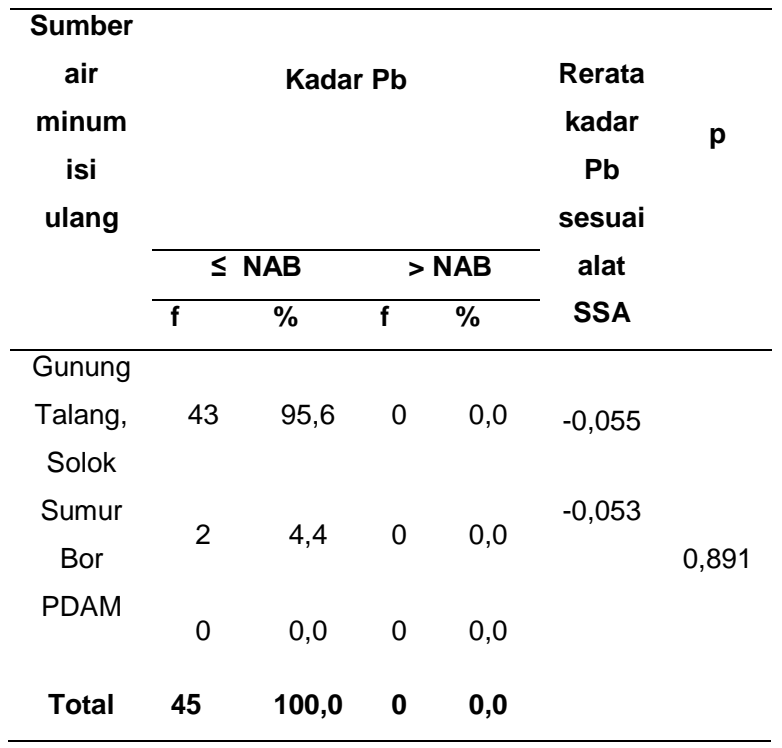

Tabel 5 menunjukkan bahwa sumber air minum yang berasal dari Gunung Talang, Kabupaten Solok maupun sumur bor memiliki kadar $\mathrm{Pb}$ di bawah atau sama dengan NAB. Hasil uji Mann-Whitney didapatkan nilai $p=0,891$ yang berarti tidak terdapat hubungan yang signifikan antara sumber air minum isi ulang dengan kadar $\mathrm{Pb}$.

Tabel 6. Hubungan Tipe Pipa PVC dengan kadar Pb

\begin{tabular}{|c|c|c|c|c|c|c|}
\hline \multicolumn{7}{|l|}{ Tipe } \\
\hline \multirow{3}{*}{$\begin{array}{l}\text { Pipa } \\
\text { PVC }\end{array}$} & \multicolumn{4}{|c|}{ Kadar Pb } & \multirow{3}{*}{$\begin{array}{c}\text { Rerata } \\
\text { kadar } \\
\text { Pb } \\
\text { sesuai } \\
\text { alat } \\
\text { SSA }\end{array}$} & \\
\hline & \multicolumn{2}{|c|}{$\leq \mathrm{NAB}$} & \multicolumn{2}{|c|}{$>$ NAB } & & \\
\hline & $f$ & $\%$ & $f$ & $\%$ & & \\
\hline AW & 45 & 100 & 0 & 0 & $-0,055$ & \\
\hline $\mathrm{D}$ & 0 & 0 & 0 & 0 & & \\
\hline $\mathrm{C}$ & 0 & 0 & 0 & 0 & & - \\
\hline Total & 45 & 100,0 & 0 & 0,0 & & \\
\hline
\end{tabular}


Tabel 6 menunjukkan bahwa pipa PVC tipe AW yang digunakan oleh seluruh sampel DAM memiliki kadar $\mathrm{Pb}$ sampel air minum isi ulangnya kecil dari atau sama dengan NAB. Tidak dapat dilakukan uji statistik terhadap hubungan tipe pipa PVC dengan kadar $\mathrm{Pb}$ karena semua DAM menggunakan pipa yang sama yaitu pipa tipe AW.

Tabel 7. Hubungan lama pemakaian pipa PVC dengan kadar $\mathrm{Pb}$

\begin{tabular}{|c|c|c|c|c|c|c|}
\hline \multicolumn{7}{|l|}{ Lama } \\
\hline \multirow{3}{*}{$\begin{array}{l}\text { Pemakaian } \\
\text { Pipa PVC }\end{array}$} & \multicolumn{4}{|c|}{ Kadar $\mathrm{Pb}$} & \multirow{3}{*}{$\begin{array}{c}\text { Rerata } \\
\text { kadar } \\
\mathrm{Pb} \\
\text { sesuai } \\
\text { alat } \\
\text { SSA }\end{array}$} & \\
\hline & \multicolumn{2}{|c|}{$\leq \mathrm{NAB}$} & \multicolumn{2}{|c|}{$>$ NAB } & & \\
\hline & $f$ & $\%$ & f & $\%$ & & \\
\hline$<5$ tahun & 23 & 51,1 & 0 & 0,0 & $-0,058$ & \\
\hline$\geq 5$ tahun & 22 & 48,9 & 0 & 0,0 & $-0,051$ & 0,166 \\
\hline Total & 45 & 100,0 & 0 & 0,0 & & \\
\hline
\end{tabular}

Tabel 7 menunjukkan bahwa pemakaian pipa $\mathrm{PVC}<5$ tahun terdapat pada $23 \mathrm{DAM}$ yang kadar $\mathrm{Pb}$ sampel airnya kecil dari atau sama dengan NAB. Sedangkan pemakaian pipa PVC $\geq 5$ tahun sebanyak 22 DAM yang kadar $\mathrm{Pb}$ sampel airnya juga kecil dari atau sama dengan NAB. Hasil uji Mann-Whitney didapatkan nilai $P=0,166$. Sehingga kesimpulan dari tabel diatas tidak terdapat hubungan yang signifikan antara lama pemakaian pipa PVC yang digunakan pada proses pengolahan air minum isi ulang dengan kadar $\mathrm{Pb}$.

\section{PEMBAHASAN}

\section{Kadar $\mathbf{P b}$}

Data memperlihatkan seluruh sampel air minum isi ulang pada DAM di Kecamatan Padang Timur memiliki kadar $\mathrm{Pb}$ kecil dari atau sama dengan nilai ambang batas (NAB) yaitu $\leq 0,01 \mathrm{mg} / \mathrm{L}$. Hal ini menggambarkan seluruh air minum isi ulang pada DAM di Kecamatan Padang Timur bebas dari bahaya logam $\mathrm{Pb}$. Penelitian yang pernah dilakukan di luar
Kota Padang salah satunya adalah di Pekanbaru oleh Subardi Bali (2012). Hasil penelitian tersebut didapatkan kadar $\mathrm{Pb}$ telah melebihi ambang batas yakni berkisar antara 0,11-0,55 mg/L untuk air baku dan 0,11-1,87 mg/L untuk air minum isi ulang. ${ }^{18}$

Perbedaan ini disebabkan karena Kecamatan Padang Timur tidak memiliki pabrik dengan limbah $\mathrm{Pb},{ }^{19}$ terutama yang menggunakan sumur bor dengan berbagai macam kandungan mineral akibat pengendapan di dalam tanah memiliki kemungkinan kecil terkontaminasi oleh $\mathrm{Pb}$. Sumber air minum terbanyak pada DAM di Kecamatan Padang Timur ini berasal dari Gunung Talang Kabupaten Solok yang berkemungkinan besar bebas dari $\mathrm{Pb}$ karena sumber air minum yang berasal dari pegunungan memiliki kualitas yang terjamin dan terlindungi dari cemaran kimia dan mikrobiologi yang bersifat merusak/mengganggu kesehatan. ${ }^{1}$

Lain halnya dengan Kota Pekanbaru yang memiliki pabrik dengan limbah $\mathrm{Pb}$ yaitu pabrik cat yang bermungkinan menyebabkan kontaminasi air baku terhadap $\mathrm{Pb}$. Tingginya kadar $\mathrm{Pb}$ pada air minum isi ulang kemungkinan dikarenakan pada proses pengolahan air baku terkait penyaringan yang digunakan dan sumber air baku yang telah tinggi juga sebelumnya. ${ }^{18}$

\section{Sumber Air Minum Isi Ulang}

Data menunjukkan bahwa sumber air minum isi ulang paling banyak berasal dari pegunungan yaitu Gunung Talang yang berada di Kabupaten Solok yaitu sebesar $95,6 \%$ dan hanya $4,4 \%$ berasal dari sumur bor. Hal ini sesuai dengan hasil penelitian yang dilakukan oleh Wandrivel et al. (2012) tentang Depot Air Minum Isi Ulang di Kecamatan Bungus Padang. Penelitian tersebut memperoleh data sebesar $55,6 \%$ sumber air minum pada DAM di Kecamatan Bungus berasal dari Gunung Talang Kabupaten Solok. Sedangkan 33,1\% berasal darisperbukitan sekitar Bungus dan $11,1 \%$ berasal dari PDAM. ${ }^{1}$

\section{Tipe Pipa PVC}

Seluruh DAM di Kecamatan Padang Timur tahun 2017 menggunakan pipa tipe AW (100\%) jika 
dilihat dari data yang didapatkan. Belum ditemukan penelitian yang meneliti tentang pemakaian tipe pipa PVC ini. Tetapi menurut teori, pipa tipe AW merupakan tipe pipa PVC satu-satunya yang dapat digunakan untuk saluran air minum yang bertekanan (menggunakan pompa) yang sesuai dengan kondisi mesin DAM sendiri. ${ }^{15}$ Apabila digunakan pipa tipe D atau $\mathrm{C}$ hal ini dapat menyebabkan pipa pecah akibat ketidakmampuan dalam menahan tekanan dari pompa mesin pengolahan DAM. ${ }^{15}$

\section{Lama Pemakaian Pipa PVC}

Ada 23 DAM yang diambil sampelnya menggunakan pipa PVC dengan lama pemakaian kurang dari 5 tahun $(51,1 \%)$ dan sisanya lebih dari sama 5 tahun (48,9\%). Namun, narasumber saat diwawancara mengatakan pipa PVC hanya akan diganti apabila mengalami kebocoran atau kondisi dalamnya sudah kotor. la menambahkan bahwa pipa PVC tidak dapat dibersihkan namun harus diganti, lain halnya dengan tangki dan penyaringan yang dapat dibersihkan secara manual.

\section{Hubungan Sumber Air Minum Isi Ulang dengan Kadar $\mathbf{P b}$}

Data pada Tabel 5 menunjukkan semua sumber air minum isi ulang baik yang berasal dari Gunung Talang Kabupaten Solok maupun sumur bor memiliki kadar $\mathrm{Pb}$ kecil dari atau sama dengan NAB yaitu $\leq 0,01 \mathrm{mg} / \mathrm{L}$. Untuk melakukan uji hubungan digunakan nilai kadar $\mathrm{Pb}$ sesuai pembacaan alat SSA. Nilai negatif pada pembacaan alat menunjukkan bahwa kadar $\mathrm{Pb}$ pada sampel air minum isi ulang dalam rentang dibawah dari ambang minimal pembacaan alat sampai dengan nol. ${ }^{20}$ Alat mampu mendeteksi sampel dengan kadar $\mathrm{Pb}$ 0,02 mg/L ke atas. Ambang batas minimal pembacaaan alat adalah $0,02 \mathrm{mg} / \mathrm{L}^{21}$ Uji yang dilakukan adalah uji $\mathrm{T}$ tidak berpasangan. Namun karena data tidak memenuhi syarat, maka dilakukan uji alternatif yaitu uji MannWhitney dan diperoleh $P=0,891$. Sehingga didapatkan kesimpulan bahwa tidak terdapat hubungan yang signifikan antara sumber air minum isi ulang dengan kadar $\mathrm{Pb}$.
Hal ini dikarenakan sumber air minum yang berasal dari pegunungan memiliki kualitas yang terjamin dan terlindungi dari cemaran kimia dan mikrobiologi yang bersifat merusak/mengganggu kesehatan. ${ }^{1}$ Gunung Talang memiliki kualitas air baku yang terjamin terbukti dari pendirian salah satu pabrik Air Minum Dalam Kemasam (AMDK). AMDK tersebut merupakan produk air minum yang telah dikenal dan tersebar di seluruh Indonesia.

Data yang didapatkan ternyata dua DAM yang menggunakan sumber air minum yang berasal dari sumur bor. Sumber air minum yang berasal dari sumur bor memerlukan alat penyaringan yang lebih canggih terkait banyaknya pengendapan logam seperti timbal $(\mathrm{Pb})$, besi $(\mathrm{Fe})$, kadmium $(\mathrm{Cd})$ dan lain-lain yang terkandung pada air dari sumur bor tersebut ketimbang air pegunungan.

Salah satu DAM yang dikunjungi peneliti yang sumber air bakunya berasal dari sumur bor sebagai sumber airnya menggunakan teknik reverse osmosis sebagai penyaringan airnya. Reversed osmosis (RO) adalah suatu proses pemurnian air melalui membran semipermeabel dengan tekanan tinggi (50-60 pound per square inchi (psi)). Membran semipermeabel merupakan selaput penyaring skala molekul yang dapat ditembus oleh molekul air dengan mudah, akan tetapi tidak dapat atau sulit dilalui oleh molekul lain yang lebih besar dari molekul air. Membran $\mathrm{RO}$ menghasilkan air murni 99,99\%. Diameternya 0,0001 mikron (500.000 kali lebih kecil dari sehelai rambut). Fungsinya adalah untuk menyaring mikroorganisme seperti bakteri, virus maupun logam berat. Teknik penyaringan $\mathrm{RO}$ ini mencegah terkandungnya $\mathrm{Pb}$ dalam air minum hasil olahan DAM tersebut. ${ }^{22}$

Kadar pencemaran $\mathrm{Pb}$ yang berasal dari limbah pada tiap daerah juga berbeda-beda. Di Kota Padang terkhusus Kecamatan Padang Timur tidak ditemukan pabrik dengan limbah $\mathrm{Pb} .{ }^{19}$ Sehingga sumber air yang menggunakan sumur bor kemungkinan memiliki kadar $\mathrm{Pb}$ yang sangat kecil bahkan mungkin tidak ada.

\section{Hubungan Tipe Pipa PVC dengan Kadar Pb}

Tabel 6 memperlihatkan bahwa pipa PVC tipe AW yang digunakan oleh seluruh DAM memiliki kadar 
$\mathrm{Pb}$ air minum isi ulang kecil atau sama dengan NAB. Tidak dapat dilakukan uji statistik terhadap hubungan tipe pipa PVC dengan kadar $\mathrm{Pb}$ karena semua DAM menggunakan pipa yang sama yaitu pipa tipe AW.

Tekanan air pada pipa PVC yang tinggi dapat menyebabkan tingginya ekstraksi dari $\mathrm{Pb}$ itu sendiri. Pipa tipe AW memiliki kemungkinan mengekstraksikan $\mathrm{Pb}$ lebih besar daripada pipa PVC tipe D dan C. ${ }^{16}$

Pemakaian pipa PVC tipe AW dalam rentang waktu pemakaian paling lama dari data yang didapatkan peneliti, yaitu 15 tahun ditemukan kadar $\mathrm{Pb}$ masih dibawah atau sama dengan NAB yang dapat dikatakan masih dalam batas yang aman untuk digunakan.

\section{Hubungan Lama Pemakaian Pipa PVC dengan Kadar $\mathbf{P b}$}

Pada tabel 7 didapatkan data lama pemakaian pipa PVC yang kurang dari 5 tahun maupun lebih dari sama 5 tahun memiliki kadar $\mathrm{Pb}$ air minum isi ulang kecil dari atau sama dengan NAB. Uji yang dilakukan untuk mengetahui hubungan lama pemakaian pipa PVC dengan kadar $\mathrm{Pb}$ air minum isi ulang adalah uji $\mathrm{T}$ tidak berpasangan. Namun karena data juga tidak memenuhi syarat, maka dilakukan uji alternatif yaitu uji Mann-Whitney dan diperoleh $P=0,166$. Sehingga didapatkan kesimpulan bahwa tidak terdapat hubungan yang signifikan antara lama pemakaian pipa PVC dengan kadar $\mathrm{Pb}$ air minum isi ulang.

Tidak terdapatnya hubungan kemungkinan dikarenakan banyak faktor yang mempengaruhi ekstraksi $\mathrm{Pb}$ terhadap air yang mengalir di dalam pipa PVC pada DAM yaitu suhu dan $\mathrm{pH}$ air saat melewati pipa PVC serta luas permukaan pipa PVC yang dilewati air. Hal ini dibuktikan dari penelitian yang dilakukan oleh Zhang et al yang mendapatkan kesimpulan bahwa ekstraksi dari $\mathrm{Pb}$ dalam pipa PVC akan meningkat seiring dengan peningkatan suhu air saat melewati pipa PVC. $^{23} \mathrm{Hal}$ ini dikarenakan semakin tinggi suhu maka pergerakan partikel di dalam pipa PVC akan semakin cepat sehingga pelepasan dari $\mathrm{Pb}$ juga semakin meningkat. $^{23}$

Penelitian oleh Koh et al. membuktikan bahwa $\mathrm{pH}$ air juga mempengaruhi ekstraksi dari $\mathrm{Pb}$. $\mathrm{pH}$ air yang semakin rendah akan meningkatkan ekstraksi dari $\mathrm{Pb}$ pada pipa PVC. $^{24} \mathrm{Hal}$ ini disebabkan air dengan $\mathrm{pH}$ yang rendah mengandung banyak anion seperti $\mathrm{Cl}^{-}, \mathrm{HPO}^{2-}, \mathrm{HCO}^{3-}, \mathrm{NO}^{3-}$, dan $\mathrm{SO}^{2-}$. Anion ini dapat meningkatkan terlepasnya $\mathrm{Pb}$ dari pipa $\mathrm{PVC}^{24}$

Terkait luas permukaan pipa PVC, penelitian oleh Tiedeman membuktikan bahwa semakin luas permukaan pipa PVC, ekstraksi Pb juga akan semakin meningkat. ${ }^{25} \mathrm{Hal}$ ini disebabkan karena semakin luas permukaan pipa PVC, kadar $\mathrm{Pb}$ yang terkandung pada pipa tersebut juga semakin banyak, yang pada akhirnya akan meningkatkan kontak air terhadap pipa. $^{25}$ Sedangkan, diketahui bahwa luas permukaan pipa PVC pada tiap DAM berbeda karena panjang dari pipa PVC tiap DAM juga tidak sama.

\section{SIMPULAN}

Sumber air minum isi ulang pada DAM di Kecamatan Padang Timur Kota Padang memiliki kadar $\mathrm{Pb}$ aman yaitu kecil dari atau sama dengan NAB yang diizinkan oleh pemerintah. Air minum isi ulang aman untuk dikonsumsi dilihat dari kadar $\mathrm{Pb}$, namun disarankan untuk dilakukan pemeriksaan lain yakni pemeriksaan mikrobiologis.

\section{DAFTAR PUSTAKA}

1. Wandrievel R, Suharti N, Lestari Y. K Kualitas Air minum yang diproduksi depot air minum isi ulang kecamatan Bungus Padang berdasarkan Persyaratan Mikrobiologi. Jurnal Kesehatan Andalas. 2012;1(3):129.

2. Harsojo H, Darsono D. Studi kandungan logam berat dan mikroba pada air minum isi ulang. Ecolab. Juli 2014;8(2):53-4. 
3. Nuraini. Analisis logam berat dalam air minum isi ulang (AMIU) dengan menggunakan spektofotometri serapan atom (SSA). Gravitasi. Januari-Juni 2015;14(1):37-9.

4. Kementerian Kesehatan RI (Kemenkes Rl). Laporan nasional riset kesehatan dasar tahun 2010. Jakarta: Badan Penelitian dan Pengembangan Kesehatan Kemenkes Rl; 2010.

5. Handayani L, Riswati, Lestari D, Aimanah I, Ipa M, editors. Riset kesehatan dasar dalam angka propinsi Sumatera Barat. Jakarta: Badan Penelitian dan Pengembangan Kesehatan Kementerian Kesehatan Rl; 2013.

6. Faradika V. 18 persen depot air minum di padang tidak memenuhi syarat. Padang: Antara Sumbar; 2015 [Oktober 2017]. Tersedia dari: http://antarasumbar.com/berita/160649/18-persendepot-air-minum-di-padang-tidak-memenuhisyarat.html

7. Kemenkes RI. Peraturan menteri kesehatan Republik Indonesia nomor 492/MENKES/PER/IV/ 2010 tentang persyaratan kualitas air minum. Jakarta: Kemenkes RI; 2010.

8. Sunarya Y. Kimia dasar berdasarkan prinsipprinsip kimia terkini. Edisi Revisi. Bandung: Angkasa; 2007.

9. WHO. Lead in drinking water. USA: WHO; 2011 [Oktober 2017]. Tersedia dari: http://www.who.int/ water sanitation health/dwg/chemicals/lead.pdf

10. Putri RZ. Hubungan konsentrasi timbal dalam air perusahaan daerah air minum (PDAM) dengan kejadian hipertensi di desa Sijantang Koto kecamatan Talawi Kota Sawahlunto Sumatera Barat [skripsi]. Padang: Universitas Andalas; 2017.

11. Purba DF. Analisis pencemaran logam berat pada air sumur bor dengan metode spektrofotometri untuk dapat digunakan sebagai air minum di kecamatan Medan-Belawan [skripsi]. Medan: Universitas Sumatera Utara; 2009.
12. Firmansyah MA, S, Utami PI. Analisis kadar logam berat timbal di mata air pegunungan guci dengan metode spektrofotometri serapan atom. Pharmacy. Desember 2012;9(3):1.

13. Schmitz G, Lepper H, Heidrich M. Toksikologi. Dalam: Sigit JI, Hanif A, editor. Farmakologi dan Toksikologi. Jakarta: Buku Kedokteran EGC; 2003. 643.

14. Hasanudin Ml. Kajian dampak penggunaan plastik PVC terhadap lingkungan dan alternatifnya di Indonesia [tesis]. Depok: Universitas Indonesia; 2008.

15. Direktorat Pembinaan Sekolah Menengah Kejuruan. Pengetahuan bahan plambing 2: Jakarta: Departemen Pendidikan Nasional; 2013.

16. Hill A. Using the right piping material for your plumbing appication. Facility Management. 2009.

17. Widowati, Sastiono WA, Jusuf R. Efek toksik logam. Yogyakarta: Andi Publishers; 2008.

18. Bali S. Kandungan logam berat (timbal, kadmium), amoniak, nitrit dalam air minum isi ulang di Pekanbaru. Health Care. Desember 2012;2(1):3.

19. Dinas Tenaga Kerja dan Perindustrian. Data industri logam, elektronika dan telematika. Padang: Dinas Tenaga Kerja dan Perindustrian; 2017 [Januari 2018]. Tersedia dari: http://disnakerin. padang.go.id

20. Djalil SH, Sirajuddin S, Zakaria. Analisis kadar logam timbal $(\mathrm{Pb})$ pada pangan jajanan di SDN kompleks Lariangbangi Kota Makassar. Jurnal Universitas Hasanuddin. Agustus 2014;2(5):5-6.

21. Erdayanti P, Hanifah TA, Anita S. Analisis kandungan logam timbal pada sayur kangkung dan bayam di jalan Kartama Pekanbaru secara spektrofotometri searapan atom. JOM FMIPA. Februari 2015;2(1):81.

22. Sembiring SY. Manajemen pengawasan sanitasi lingkungan dan kualitas bakteriologis pada DAM isi ulang di Kota Batam [tesis]: Universitas Sumatera Utara; 2008. 
23. Zhang Y, Lin YP. Leaching of lead from new unplasticized polyvinyl chloride (UPVC) pipes into drinking water. 2015 Jun;22(11):8405-11.

24. Koh LL, Wong MK, Gan LM, Yap CT. Factors affecting the leaching of lead from UPVC pipes. 1991 Oct;19(1):203-13.

25. Economic and Engineering Services Inc. Lead control strategies Colorado. US: American Water Works Association Research Foundation; 1990. 